later this year. Nevertheless, a second firm offer of a site for the laboratory has now been made. As well as the offer of a site near Nice by the French Government last year, there is now the prospect of an Italian site near Rome.

At this stage, however, it seems that enthusiasm among some governments is more than counterbalanced by the scepticism of others. The West German Government, for example, seems to take the view that at this stage any attempt by EMBO to force the pace of a decision on the laboratory would invite refusal. Other governments, the British among them, take the line that the first step should be to make a decision about collaboration and continuing financing of the programme of fellowships and exchange visits on which EMBO has already embarked, chiefly with money from the Volkswagen Foundation. From this point of view, the laboratory is likely to become a live issue only towards the end of 1968 , although there may be some discussion of it at the next governmental meeting arranged for April.

From EMBO's point of view, however, it is somewhat disconcerting that even the less ambitious set of proposals for fellowships and exchanges may not command full support by the next meeting. Although several delegations last week are known to have come out in favour of the fellowships, both the British and Belgian Governments-for different reasons-took a more negative line.

The British view seems to have been determined by recognition, rather late in the day, that even the proposal to finance EMBO fellowships on a continuing basis raises awkward issues of principle which have not yet been given the attention they deserve. There is, for example, the issue why molecular biology should be singled out for special treatment. There is also a fear that massive support for EMBO would serve unhealthily to institutionalize molecular biology. In more practical terms, although the amounts of money involved in financing the fellowships (as distinct from the laboratory) are comparatively small, it is inevitable, now that forward planning within a fixed budget has become everybody's watchword, that funds for EMBO will have to come out of somebody else's budget.

The difficulty here is that the Medical Research Council-one obvious source of finance-is likely to decide that it knows of better ways of spending its own money. At the same time, it is unlikely that the Royal Society would take kindly to a government instruction that a large part of the $\$ 200,000$ a year which it has been allotted for European fellowships in all fields should in future be earmarked for EMBO. The result, in Britain, is most probably that the government will try to resolve its difficulties by a process of enquiry and consultation within the research councils and the Council for Scientific Policy. There may be some interest to see whether it can clear up its genuine difficulties without seeming to use consultation as a means of procrastination.

\section{Franco-Soviet Space Agreement}

Some details have now been made available of the Franco-Soviet space agreement signed in Moscow on December 9. The agreement calls for the launching of a satellite containing an experiment of French design to make a spectroscopic analysis of the Moon's atmo- sphere, if it has one. The satellite will be launched at the end of this year or early in 1969 .

Observations made during eclipses have given grounds for believing that the Moon may contain a thin atmosphere, produced, it is surmised, by volcanic eruption of gases or by radioactive decay of surface rocks, for example, of potassium into argon. Another possibility is that the high energy particles in solar winds might erode the lunar surface to the extent of releasing hydrogen and helium atoms; these might be retained by the Moon's gravitational field for brief periods. Any lunar atmosphere will probably be so tenuous that the exhaust gases from lunar landings could radically alter its composition; the experiment must therefore be performed as quickly as possible.

Another project outlined in the Franco-Soviet agreement is a study of the magnetic fields of the Moon. It has not yet been confirmed whether the USSR will make use of the French base at Kourou in Guyana for the launching of a manned satellite.

\section{New Nature Reserve}

The decision of the Natural Environment Research Council to establish a National Nature Reserve on about 182 acres of Cors Fochno, otherwise known as Borth Bog, in Cardiganshire, will be good news to many ecologists. There can now be no danger that draining will destroy a fine example of a relatively undisturbed raised bog.

Borth Bog is on the southern side of the estuary of the River Dovey and is an extensive area of acid peat which is in some places as much as twenty-three feet deep. The vegetation is very rich in mosses, and especially the genus Sphagnum-also known as bog moss. Among the species present is Sphagnum imbricatum, a peat-forming moss which is now quite rare in Britain. One of the problems now puzzling botanists is why this moss, which must have been the commonest when peat formation was progressing rapidly, has now become almost extinct.

Among the flowering plants there are no great rarities, but there are some interesting species. Andromeda polifolia, or bog rosemary, the pink flowered low woody plant, which is found on Borth Bog, is now decreasing on the bogs in the north and west of Britain. All three species of Drosera, the plant which catches insects on its sticky leaves, are found in close proximity at Borth, and this is a very rare occurrence. The faune also has its interest; polecats, the stoat-like carnivores which are now rare except in central Wales, are numerous, and seventy-four species of butterflies and moths and twenty-two species of breeding birds have been identified.

As well as the distribution of the vegetation on the surface of the bog, and the effect on it of changes in the habitat, such as water movement, there is great interest in the history of the bog. Analysis of borings into the peat has revealed that the bog developed from fenland, later to be covered by forest, dominated by a sequence of different trees. The base of the bog is clay, contain. ing Foraminifera-the fossil Protozoa which usually had a hard outer coat. Peat samples from $24 \mathrm{~cm}$ above the base of the bog contain less pollen from trees than from other plants, mainly monocotyledons, which suggests that this was fenland. The trees were elm, pine, oak and hazel. Samples from 34-54 cm 
above the base of the bog contain more pollen from trees than from other plants, with a marked preponderance of alder and birch pollen. The fen was evidently covered by forest, first dominated by alder, and later by birch. At 100-180 cm above the base the proportion of tree pollen decreases and there are many spores of the moss Sphagnum, and pollen of the small aromatic plant Myrica gale, also known as sweet gale or bog myrtle. The transition from fenwoods to raised bogthe peculiarity of a raised bog is that it has developed from the less acid fen-appears to be about $100 \mathrm{~cm}$ from the base of the profile.

- This sequence resembles closely that found in the submerged forest which stretched intermittently between high and low tide marks for two miles along the coast between the villages of Borth and Ynyslas to the north. On the beach at Ynyslas there are exposed remains of tree trunks which were part of this forest.

\section{Sorry, for copyright reasons some images on this page may not be available online}

\begin{abstract}
Borth Bog, Cardiganshire, looking south-east. The Nature Reserve is shown in the middle distance. (Crown copyright; Dr J. K. S. St. Joseph.)
\end{abstract}

There is still much to be learnt about the historical aspect of Borth Bog. Dr Peter Moore of King's College, London, has recently made a series of borings in bogs, including Borth, and built up a historical picture of the human influence on the vegetation of central Wales. Pollen analysis can show, by such signs as the presence of a high proportion of weed pollen in peat samples, that man has been active in an area. There is other work in progress which is concerned with similar aspects of the history of Borth $\mathrm{Bog}$, as well as various ecological studies on the surface, despite the impression given by the apparent paucity of published results. It will all be able to continue unhampered when the Nature Reserve is set up.

\section{Documentation for Planning}

Housing, building and planning are subjects which cut right across the conventional disciplines. As a result, the literature is diffuse and it is also inundated with trade material, good and bad, in enormous quantities. These problems make the proper organization of literature in the fields of housing, building and planning complicated, to say the least. There is not too much wrong with the two-way flow of information between North America and the countries of Western Europe, but it is a different story with Eastern Europe, Asia and Africa. There are the usual language difficulties, and most developing countries have far from sophisticated library and information services. It is hoped, however, that a new organization, an International Institute for Documentation of Housing, Building and Planning, will help. A talk about this was given recently at Aslib headquarters by $\mathrm{Mr}$ Agard Evans, former Chief Librarian, Ministry of Public Building and Works.

There are already in existence several organizations concerned with building and planning on an international scale-the International Council for Building Research, Studies and Documentation (CIB), and the International Federation for Housing and Planning, for example. None of the international bodies, however, appcars to have the terms of reference, the funds or the facilities to cover documentation in building and planning on a world-wide scale. This is why it is proposed to set up a new institute which would be able to channel all its energies and resources into the problems of documentation. The Economic and Social Council of the United Nations has had the institute in mind for some time. Before giving final approval to the project, the council asked that an expert group of four from India, Czechoslovakia, France and Britain should undertake a feasibility study. The group, of which Mr Evans was the British member, met twice lest summer and presented a unanimous report to the council in September. A draft resolution was approved and this is to be put before the full council meeting in May this year.

In outline, the proposal is to ostablish the headquarters of the institute in New Delhi. This will be supported by national documentation centres in each membor country. Staff in New Delhi, documentalists, translators and others, will disseminate information on housing, building and planning in various waysthrough "digests" (extended summaries of a selected number of primary documents, 100 per month); annotated references; abstracts (selected from those already published in the field); and "syntheses" (reviews of the subjects from primary and secondary sources). These services would be in four languagesEnglish, French, Russian and Spanish. The national centres would assist in all this by making the information available to practitioners in their country. The institute in New Delhi would also act as an information centre for queries which cannot be answered from existing national sources. If necessary, queries could be channolled to the other international centres. Secondary functions of the institute could include standardiza- 